\title{
China's Policy to Close Borders to Prevent the Spread of the Second Wave of COVID-19 Virus
}

\section{Elyta}

Universitas Tanjungpura

E-mail:elyta@fisip.untan.ac.id

Syarifah Ema Rahmaniah

Universitas Tanjungpura

E-mail:syf.ema@fisip.untan.ac.id

\section{Hendra Ramdani}

Universitas Tanjungpura

E-mail: ramdanihendra83@gmail.com

\begin{abstract}
At the end of 2019, the world was taken aback by the outbreak of the COVID-19 virus, which first emerged from Wuhan. The increase in cases of local transmission in China's border region with Russia has sparked new concerns. In this paper, data were collected by literature study from journals and electronic books, including data from trusted websites through internet searches in the form of soft files as a method supporting the paper's explanation. From this paper's results, the readers can see several essential points explaining how China's policy to close the border in Russia to stave off the spread of COVID-19. First is how the procedures are carried out by China in tightening surveillance on Russian borders, and second, knowing how China monitors its citizens using cellphones.
\end{abstract}

Keywords: COVID-19, Border, China, Russia

\begin{abstract}
Abstrak
Pada akhir tahun 2019, dunia dibuat terkejut dengan mewabahnya virus COVID-19 yang pertama kali mucul dari Wuhan. Meningkatnya kasus penularan lokal di wilayah perbatasan China dengan Rusia telah memicu kekhawatiran baru. Pada tulisan ini, data dikumpulkan dengan
\end{abstract}


studi pustaka dari jurnal dan buku elektronik termasuk data dari website terpercaya melalui pencarian internet dalam bentuk soft file sebagai metode yang dapat mendukung penjelasan makalah. Dari hasil tulisan ini, pembaca dapat melihat terbagi menjadi beberapa poin penting yang menjelaskan bagaimana kebijakan China menutup perbatasan di Rusia untuk mencegah penyebaran virus COVID-19 di negaranya, pertama, bagaimana prosedur yang dilakukan. oleh China dalam memperketat pemeriksaan di perbatasan Rusia. Dan kedua, mengetahui bagaimana China memantau warganya dengan menggunakan telepon seluler.

Kata kunci: COVID-19, Perbatasan, China, Russia

\section{INTRODUCTION}

In early 2020, the world was shocked by the outbreak of a new virus, namely a new type of Coronavirus (Severe Acute Respiratory Syndrome Coronavirus- 2 or SARS-CoV-2), and the name of the disease is called Coronavirus disease 2019 (COVID-19). At first, this virus was known to have originated from Wuhan, China, and this virus was discovered at the end of December 2019 (Yuliana, 2020). In the maintenance of human security globally, the pandemic became an opponent (Elyta et al., 2020).

China reported a case of this mysterious virus on January 5, 2020. The virus infected 41 people, and one person was declared dead. The World Health Organization (WHO) finally identified this mysterious virus as a new virus called Novel Coronavirus, known as 2019-Nov (Zhahrina, 2020). This incident began in Wuhan, where 27 people were reported to have suffered from pneumonia-like illness, fever, difficulty breathing, and abnormal lungs. Infection of 1,700 people cases of this transmission occurred from December 8, 2019, to January 2, 2020; the number continued to increase until it infected 59 people. The spread of this virus originated from one of the seafood markets in Wuhan City. Apart from food and sea animals, this market also sells rabbits, snakes, and other poultry.

Therefore, experts initially suspected that this virus was related to the SARS and MERS cases that had plagued Saudi Arabia and China. A 55-year-old person from 
Hubei province, China, was the first to contract of new Coronavirus that has spread worldwide. The search found that the initial case was detected on November 17, 2019, which found that after the November 17 case, around one to five new points were reported each day, and as of December 15, total infections hit 27. Daily issues appeared to have increased since then, with the number of cases reaching 60 on December 20. On December 27, Dr. Zhang Jixian, the head of the respiratory department at the Hubei Provincial Hospital, reported to health officials in China that the new Coronavirus was causing the disease COVID-19; on that day, it infected more than 180 people. Authorities had so far identified at least 266 people who were infected last year. Several cases were confirmed after health authorities tested specimens from suspected COVID-19 patients. The head of the respiratory department at the Hubei Provincial Hospital reported to health officials in China that the new Coronavirus causes the disease COVID-19; on that day, it infected more than 180 people. Authorities have so far identified at least 266 people who were infected last year. Several cases were confirmed after health authorities tested specimens from suspected COVID-19 patients. The respiratory's head department of Hubei Provincial Hospital said that the new Coronavirus causes the disease COVID-19; it infected more than 180 people on that day. Authorities have so far identified at least 266 people who were infected last year. Several cases were confirmed after health authorities tested specimens from suspected COVID-19 patients.

The discovery was a month earlier than a doctor's note in Wuhan, China, which said the Coronavirus's spread occurred at the end of December 2019. At that time, the authorities suspected that COVID-19 originated from something sold in the Wuhan wet market. However, it is now clear that some of the infected people have no connections or have never been to the market, one of which was a patient who was sick on December 1, 2019.

The pandemic era has strengthened people's sense of unity to fight the virus and support each other in tough times (Elyta \& Kartikasari, 2020). Researchers have suspect that SARS-CoV-2, which originated in bats, jumped on another animal. The doctors and the experts are trying to track down the virus's 
origin to learn more about its spread (Azizah, 2020).

Coronavirus $(\mathrm{CoV})$ is a large family of viruses that cause disease in humans and animals. In humans, it usually causes respiratory tract infections, from the common cold to severe illnesses such as Middle East Respiratory Syndrome (MERS) and Severe Acute Respiratory Syndrome (SARS). A new type of Coronavirus discovered in humans since the outbreak occurred in Wuhan, China, in December 2019, was then given the name Severe Acute Respiratory Syndrome Coronavirus 2 (SARSCOV2) and caused disease with the name Coronavirus Disease-2019 or COVID-19. Coronaviruses are zoonotic (transmitted between animals and humans). Research stated that SARS-CoV is transmitted from civet cats (civet cats) to humans and MERS-CoV from camels towards humans.

On the other hand, the border area is the gateway to a country. The border area is a meeting area between two administrative regions. Still, natural resources and the people can be a complementary part of a functional system unit to develop a supported site (Budianta, 2010). State border areas are the primary manifestation of a country's territorial sovereignty.
Problems with borders have very complex dimensions. The definition of a border, in general, is also a demarcation line between two sovereign states. At first, they formed the edge of a country or state border with the state's birth. Previously, residents who lived in certain areas did not feel the difference, even though they often came from the same ethnicity.

Regarding the issue of the Coronavirus, it is currently rife in various parts of the world. Even the Coronavirus is no longer an epidemic that is just ordinary but has become a pandemic of disease that is extremely dangerous to people in various countries. Of course, it has a significant impact on the welfare of the country. In response to the ongoing Coronavirus pandemic, many countries are more intensive in increasing security in their border areas.

It is undoubtedly a government effort to minimize the Coronavirus's chain to enter the country. In this case, the Chinese method of recovering from COVID-19 uses three strategies, namely: (1). Shut down and hold. In January, China effectively shut down Wuhan, putting its 11 million people under strict quarantine. Other cities followed this in Hubei Province. 
Meanwhile, in different regions throughout China, the local government insisted on prohibiting its citizens from going out and staying at home.

Since then, extreme social distancing and self-quarantine have been followed by other countries in Europe, including several US states. Nevertheless, a study presented by Imperial College London showed the strategy could have economic and social implications. In published studies, the main challenge with these measures is that they must maintain them until the vaccine is ready in 18 months.

(2). Mass Mobilization. The central government moved swiftly to deploy 42,000 doctors and nurses to Hubei to help the local medical team become overwhelmed. The government also sent health experts from the Chinese Red Cross to Italy, countries with the highest death rates due to COVID-19. Beijing's decision to dispatch the medical team was not without victims, referring to the Health Ministry's march figures. Based on these data, more than 3,300 doctors and nurses have tested positive for COVID-19, with 13 of them dying.

Apart from that, they were also doing something extraordinary, namely, building a hospital within two weeks to accommodate thousands of patients. The central authorities' efforts were reinforced by repeated propaganda weapons, where people were asked to live hygienically and stay at home. Also, read Chinese researchers: Coronavirus Can Infect Faster and Longer than SARS.

(3). Masks and checks in cities throughout China. Residents are asked to wear masks. They are not allowed to enter the apartment or office if they are not wearing them. The widespread use of masks can reduce the spread of the epidemic, especially for those who do not show symptoms (Ahmad Naufal Dzulfaroh, 2020).

One of the countries that have implemented increased border security to anticipate the Coronavirus's spread is China. China, which is currently a country that has managed to get through the tough times of the COVID-19 pandemic, has increased its strict surveillance of its country's borders. However, as China gradually passes through the pandemic, the neighboring countries are threatened with an increased spread of the Coronavirus. One country that poses a threat to China is Russia because both of them directly share a land border. Previously, China had experienced 
an increase in cases at the beginning of the year, but the government quickly acted to address the rise cases.

The decline in the number of new cases of the Coronavirus (COVID-19) in China, as reported by the Chinese authorities, is good news. The number of infection cases in China decreased to 202 new topics, from the usual number of thousands per day. The drop in the number of new infections in the "Bamboo Curtain" country was based on a decline in the number of cases in Hubei Province, where this deadly virus emerged. Central Hubei Province reported less than 200 cases of COVID-19 infection, to be particular 196 new cases. This figure dropped dramatically from the previous day, which reached 570 new topics. This number was also the lowest since January 24, 2020. This decline was triggered by the shrinking number of new cases in Wuhan, where the deadly virus emerged last December. The Reuters news agency revealed that there were 193 new coronavirus cases in Wuhan on Sunday, the lowest since January 24, 2020 (Zhahrina, 2020).

Moreover, the increase in local transmission cases in the border region with Russia has sparked new concerns for China. Of the several new patients whose numbers have decreased, a small proportion of cases were local transmission or domestic issues. These cases were in Heilongjiang Province and Guangdong Province. Heilongjiang Province has been at the forefront of China's battle to prevent imported cases. Many Chinese citizens returned from Russia through the border region, mostly after Russian authorities stopped international flights. Chinese authorities have closed the border crossing with Russia in Suifenhe, a city in Heilongjiang Province. Additional cases involving travelers arriving from Russia were also found in other mainland Chinese areas, including Inner Mongolia and Shanghai (Christiastuti, 2020). Due to the increase in new cases, Suifenhe and Harbin, the capital of Heilongjiang Province, imposed a quarantine rule for 28 days for those arriving from abroad. Also, these people returning from abroad were required to undergo antibody tests.

The increase in cases prompted the Chinese consulate office in Vladivostok to appeal to Chinese citizens not to use the MoscowVladivostok-Suifenhe route. Meanwhile, for Suifenhe residents, the Coronavirus case brought by Chinese citizens who returned 
from Russia made several residents afraid. It is a concern for the country because of the Coronavirus's threat spread through China's land border. The city of Suifenhe has become an area that now seems to be a new battleground against China's coronavirus outbreak.

\section{Conceptual Framework and Research Methods}

The theoretical approach in the concept of non-traditional security assumes that the safety of all political entities is under the state (state actors), apart from pressure originating from the international environment. It also comes from the domestic background in the sense that the state can become a source of threats to the security of citizens. Then, the nature of the security threat itself is multidimensional and complex because today's security threats do not only come from the military but also come from other factors, such as piracy, ethnic conflicts, environmental problems, international crimes, and so on (Perwita \& Yadi, 2006). Based on this non-traditional approach, the conception of security is emphasized in safety interests, whose actors are not stated (non-state actors).

Non-traditional security issues are widely spread in various but interrelated and sometimes overlapping areas - such as threats to the environment, nourishment, economy, energy, human security, maritime, and so on. These issues are considered to have a severe impact on all levels, be it human security, national security, regional security, or international security. The development in terms of international actors and security issues makes new global security interactions more complex and varied (Sagena, 2013).

Security is one focus of attention that all parties, both state entities and individuals, want to achieve. In contrast to the traditional discourse, which emphasizes the security of a particular state, region, or government, the concept of human security focuses on the safety of individuals and communities (Sudiar, 2018). The efforts to protect human security open opportunities for border areas to accelerate the development process, with a close link between economic development and social development.

In the scope of border studies, the concept of human security offers an alternative idea of state development that focuses on human orientation and in the context of borders (Kester, 2017)the natural gas extraction in the Netherlands has 
experienced an increasing number of ever stronger gasquakes (induced earthquakes due to gas extraction. This concept helps to formulate border development policies that are more human-oriented.

Non-traditional security (NTS) issues require inclusive diplomacy involving both state and nonstate actors. The government's limited capacity to deal with NTS issues has made the role of NGOs such as media, academics, local communities, and business actors increasingly significant. The contemporary global issue, a non-traditional security threat, is not focused on one particular country. Thus, threats that are part of contemporary global issues are not only faced by one country but have threatened many countries at once. This involvement can be maximized to reach non-state actors by opening space for dialogue between the government and these actors through public diplomacy (Amaritasari, 2017).

In viewed as a security concept, human security results in various interpretations that can be seen from multiple perspectives of the interests of power and order itself. Both these interests are carried out by state actors and non-state institutions, even individuals
(Hidayat, 2017). It is obtained from the history of human security that has been previously mentioned as a result of the shift in post-cold war security issues, which non-state actors currently dominate. As can be seen, the protection of a country's people is at stake in the spread of the COVID-19 virus. Through this, a policy that benefits its citizens is urgently needed in overcoming this pandemic virus problem.

Therefore, this research aims to analyze how a country's policies protect its people from outside interference, such as the COVID-19 virus. Through mass media reports and official reports from the Russian State, the researchers try to analyze how the development of the spread of the COVID-19 virus from before closing the two countries' borders until the implementation of the closure of the border between the two countries. To analyze this, the researchers used descriptive research and a qualitative approach. This approach was carried out by comparing how many victims and recoveries were reported by the mass media each month. The research technique used was a literature study. Researchers collected various sources that had a relationship with the problem being discussed. The sources could be in the form of 
news, newspapers, and journals with similarities, both in theory and from a case perspective.

\section{China Tightens Inspections at Russian Border}

In the case of the very rapid spread of the Coronavirus, of course, all countries are worried that the government is doing various ways to stop the spread of this pandemic. In this case, the Chinese government has agreed that there will be tests on humans, amid cases in the spread of the Coronavirus, especially from its neighbor, Russia. This step was carried out by tightening checks on Russia’s border (Laoli, 2020). In Russia, it was recorded that 409 people infected China came from the red bear country. The province that borders China's northeast with Russia, Heilongjiang, was infected with 79 new Coronavirus cases imported from Russia on Monday. These new instances currently came from Chinese nationals traveling to and returning from Russia (Laoli, 2020).

The coronavirus spread was not only imported from China itself; what the Chinese government did not expect is that the majority of those who returned from Russia had contracted the Coronavirus. In this case, the Chinese government has tightened surveillance at the border, especially the land route at the Heilongjiang border (Wu \& Tian, 2020). It would help to suppress the Coronavirus pandemic in the border area.

Also, citizens who returned from abroad to China, such as Chinese people who wanted to return to their country from Russia, had to be tightened by imposing a quarantine rule for 28 days for those who came from abroad and those who returned from abroad. It was mandatory to undergo an antibody test (BBC World, 2020). The increase in cases prompted the Chinese consulate office in Vladivostok to appeal to Chinese citizens not to use the Moscow-Vladivostok-Suifenhe route.

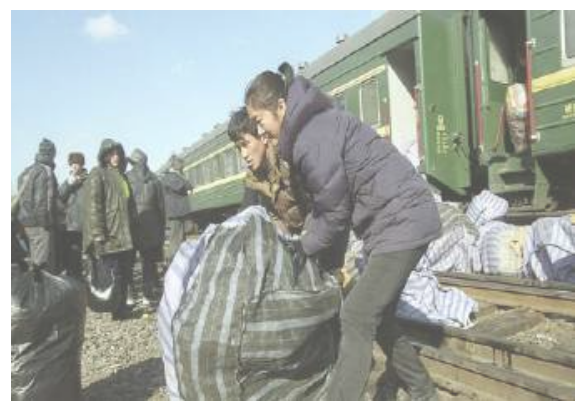

Figure 1. Russia and China are connected with the train line through Suifenhe.

Source: (BBC World, 2020)

Several cases that have recently emerged in mainland China, especially in the border area 
between China-Russia, have been reported asymptomatic. Chinese health authorities said 57 new asymptomatic patients. In total, 1,023 asymptomatic cases were still under medical supervision (BBC World, 2020).

However, it is known that Chinese authorities did not include asymptomatic cases in their official tally. Later, Chinese authorities recently launched an epidemiological survey of nine regions to determine the scale of transmission of asymptomatic patients and the overall rate of immunity.

When viewed from the increase in the coronavirus pandemic spread, it will undoubtedly worry China's economy itself. Therefore, the Chinese government made a new policy of tightening the border area because it was in the border area between China and Russia that made the spread of this virus rise again from previously, China succeeded in suppressing the spread level of this coronavirus pandemic.

Based on data, the increasing number of COVID-19 instances has been a single-digit percentage since last March 30. Most recently, on April 10, there was an increase in cases of $5.92 \%$, bringing the total to 1.52 million cases (Pransuamitra, 2020).

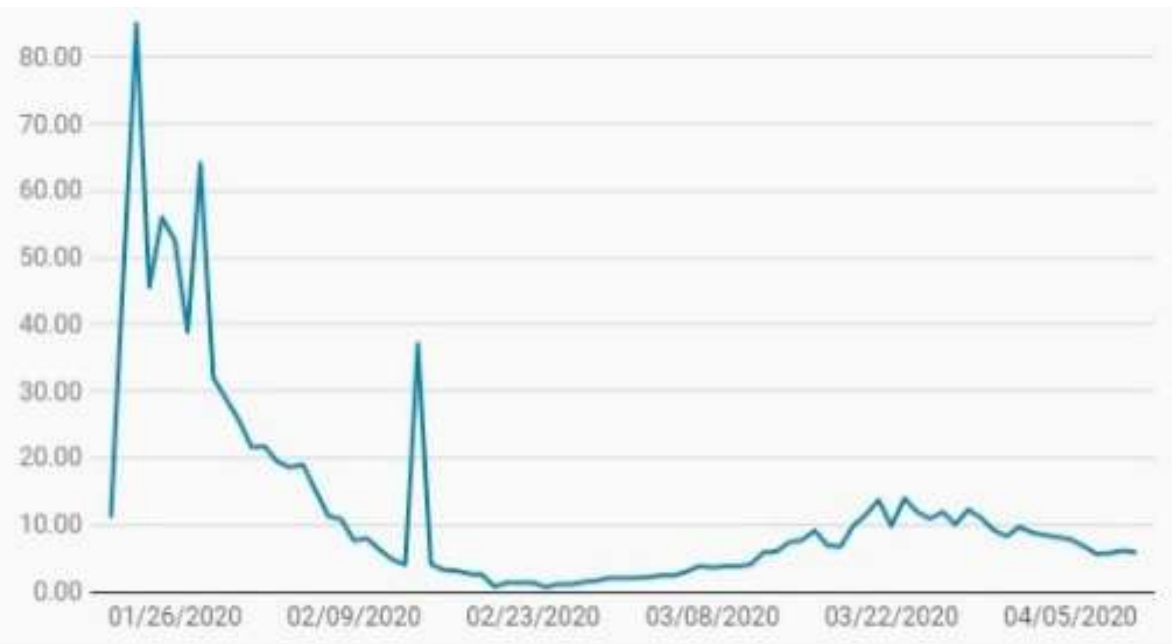

Figure 2. Increase per Day of COVID-19 Cases Globally (\%)

Source: (Pransuamitra, 2020) 
The Heilongjiang Provincial Government has started roundthe-clock patrols along its border with Russia. The two countries have agreed to close the Suifen River port on the wall, which is the main checkpoint for land transit.

With this in mind, this 3,218 $\mathrm{km}$-long border with Russia is effectively closed; Heilongjiang Province is stepping up its efforts to secure the region. China has also turned an office building near the edge into an emergency hospital, ready to accommodate a new spike in infections (Nugroho, 2020).

Until now, this policy has been continued, with the hope that China can again reduce the spread of the coronavirus pandemic. China is concerned that a second wave will occur, which is predicted to have a more severe space than the coronavirus pandemic's first spread (CNN Indonesia, 2020). The Chinese government's measures make every effort to suppress its spread. Also, China has become a reference for other countries to prevent the spread of the virus.

\section{China Closes Suifenhe Port to Reduce Spread of COVID-19}

With the COVID-19 outbreak, Heilongjiang Province has become a province that significantly influences the entry of the COVID-19 virus. It is known that about 160,000 Chinese citizens were living and working in Russia, where the virus was increasing (RFI, 2020).

China closed the Suifenhe Border Port in Heilongjiang Province to overcome the entry of the COVID-19 virus into China that came from abroad. The Chinese consulate in Vladivostok City, the Primorsky region's capital, shares a direct border with Heilongjiang Province. It has led the Chinese Consulate to warn Chinese citizens not to return through city ports (Yang, 2020).

This closure was carried out because of COVID-19 cases in Suifenhe, China's northeastern Heilongjiang Province. Residents infected with the virus were those returning from a road trip through the eastern Russian city of Vladivostok, returning from Moscow. It was followed by Russia closing all flights to China and closing all of its land borders for incoming traffic from China, including routes that pass through Suifenhe (Wu \& Tian, 2020).

In the past, residents of Suinfenhe in Heilongjiang had to stay at home, except to buy essential things for supplies, which was limited to once every three days. The 
government has also announced to close the Suinfenhe border for one week. It was because the city at the district level has exceeded the capacity to carry out quarantine and isolation of new arrivals (Sixth Tone, 2020).

Previously, all of these cases involved Chinese nationals who had returned from Russia. (Yang, 2020). Also, China implemented mandatory isolation for cities along China's northeastern border and even closed all transportation to and from neighboring Russia. It was done because of concerns about Chinese citizens' return who could bring the COVID-19 virus home and the Chinese government's closure of transportation from Wuhan City. For them, such decisive actions would control the outbreak in the country and minimize the possibility of the attack spreading internationally. Since the first case was discovered in Wuhan on December 31, 2019, hundreds of people have been infected with the Coronavirus, and 17 people have died. With hundreds of millions of people traveling across China for the Lunar New Year holiday this week, the National Health Commission has also announced measures to combat this disease. These include airport sterilization and ventilation, as well as planes and trains (Iswara, 2020).

As with many other cities, the increase in coronavirus cases was overwhelming healthcare in Suifenhe. Local authorities have requested financial assistance, surgical masks, N95 masks, and personal protective equipment. The government in Beijing dispatched equipment and a team of infectious disease experts, which among other things, was tasked with conducting tests. The Heilongiang Provincial Government also sent more than 200 medical personnel to assist medical personnel in Suifenhe. A 13-story building has been converted into a hospital that can treat 600 patients.

\section{Russia Closes Border and Stops Electronic Visas with China}

After China closed its borders to Russia, Russia was doing the same. Russia closed its borders to anticipate the spread of COVID-19 from China. Mikhail Mishutin, as the Prime Minister of Russia, said that he had held a cabinet meeting and had signed an order to close the Chinese border. Mikhail Mishutin said that the border's closure was carried out to protect its citizens from the increasing spread of the COVID-19 virus. In addition to closing the wall, there was an 
order from the President of Russia, Vladimir Putin, for its citizens not to visit or travel to China for a while. Moreover, citizens in China were asked to contact the embassy in Beijing (CNN Indonesia, 2020).

Through an official statement that has been published, the Russian Foreign Ministry would suspend the receipt of electronic visas for Chinese citizens who wished to visit Russia. The suspension was carried out through border checkpoints located far away in the East and Kaliningrad region, as well as through land, sea, road, and pedestrian checkpoints located in the area of St. Petersburg and those in the Leningrad region (Teslova, 2020). The Russian Foreign Ministry also said it was stopping granting electronic visas. Electronic visas are commonly used for Chinese citizens to cross at several Far East and western border points. The ministry also warned its citizens not to travel to China.

Deputy Prime Minister Tatyana Golikova also said that Russia had closed its border with China to pedestrian and vehicle traffic. Also, he said he would impose restrictions on rail services and would only operate between Moscow and Beijing. As for air traffic, it was still a consideration for Russia. Many Chinese citizens were being screened for the virus at airports around the world. Several airlines have made flight arrangements destined for Wuhan.

\section{China Monitors Citizens Using Cell Phones}

In areas under quarantine, phone location data is used to monitor human movement and enforce curfews. If a patient must be quarantined, their phone's geolocation will alert the government if this person leaves quarantine. Telephone location data are also used to map the exact places a person has visited during the last two weeks of diagnosis. The combination of human analysis and computer analysis can determine who may be infected by them. If this patient gets on the train and has a chance to infect people, text messages will be sent via an app used by many to warn of the risk of transmission. Each person is given a colored QR code, depending on the risks they have.

Of course, the Chinese government's policy in dealing with the spread of the coronavirus pandemic will not be optimal if it is not accompanied by the quarantine system implemented in the country. The quarantine system helps the government supervise its 
community and supervision carried out on cell phones.

Furthermore, this cybersurveillance would be useless without a strict quarantine team in China. Police and volunteers guard are in every doorway in and out of apartment blocks to ensure a quarantine occurs. China managed to reduce the rate of new infections from thousands a day at the outbreak's peak to zero within five weeks. However, in countries where surveillance is being used to deal with the Coronavirus, many fear the long-term impact.

\section{CONCLUSION}

China's best option for halting the spread of the COVID-19 chain, which includes Russia, is to tighten the border area. According to Chinese authorities, the decline in COVID-19 cases is already a good start. Citizens returning from abroad must be tightened by implementing quarantine regulations for 28 days and undergoing antibody tests. Also, in monitoring its citizens, China makes use of cell phones. Through telephone location data, the government can monitor human movement and enforce a curfew. It, of course, will be in vain if it is not supported by a strict quarantine implementation team in China.
There is assistance from the police and community volunteers to guard every doorway in and out of apartment blocks. The country, which is the leading cause of the emergence of the COVID-19 virus, has become a reference for other countries. It is because China can reduce the spread of the COVID-19 virus in just five weeks. Many countries have begun quarantine and closed border routes with other countries.

\section{REFERENCES}

Ahmad Naufal Dzulfaroh. (2020).

Cegah Penyebaran Virus Corona, Pemerintah China Tutup Akses Transportasi. Kompas.

Amaritasari, I. P. (2017). Keamanan Nasional dalam Konteks Isuisu Global Kontemporer : Sebuah Tinjauan Hubungan Internasional. Jurnal Keamanan Nasional, 3(1), 109-132. https://doi.org/https://doi. org/10.31599/jkn.v3i1.19

Azizah, K. N. (2020). Dugaan Kasus Pertama Virus Corona di China Terdeteksi pada November 2019. Detik Health.

BBC World. (2020). Medan Pertempuran Baru China Melawan Corona Ada di Kota Perbatasan Rusia. Detik News. 
Budianta, A. (2010). Pengembangan wilayah perbatasan sebagai upaya pemerataan pembangunan wilayah di Indonesia. Jurnal SMARTek, 8(1), 72-82. http://jurnal.untad.ac.id/ jurnal/index.php/SMARTEK/ article/view/628/546

Christiastuti, N. (2020). China Catat 46 Kasus Corona, Penularan di Perbatasan Rusia Bikin Khawatir. Detiknews.

CNN Indonesia. (2020). Cegah Virus Corona Masuk, Rusia Tutup Perbatasan dengan China. CNN Indonesia.

Elyta, E., \& Kartikasari, W. (2020). Strengthening the Border Tourism in Sambas District of West Kalimantan Indonesia in the Covid-19 Pandemic: A Political Boundaries Perspective. 4th International Conference on Sustainable Innovation 2020-Social, 518(December 2020), 192202. https://doi.org/10.2991/ assehr.k.210120.124

Elyta, E., Warjio, W., \& Azrin, A. (2020). Smart Human Security: Economic Safety for Micro, Small and Medium Enterprises (MSMEs) to Face the Impact of the Covid-19 Global Pandemic. Journal of Government and Civil
Society, 4(2), 181. https://doi. org/10.31000/jgcs.v4i2.2715

Hidayat, R. A. (2017). Keamanan Manusia dalam Perspektif Studi Keamanan Kritis Terkait Perang Intra-Negara. Intermestic: Journal of International Studies, 1(2), 108. https://doi. org/10.24198/intermestic. v1n2.3

Iswara, A. J. (2020). Kasus Infeksi Virus Corona: Di China Menurun, Luar China Meningkat. Kompas.

Kester, J. (2017). Energy security and human security in a Dutch gasquake context: A case of localized performative politics. Energy Research and Social Science, 24, 12-20. https://doi. org/10.1016/j.erss.2016.12.019

Laoli, N. (2020). China Perketat Pemeriksaan di Perbatasan Rusia dan Setuju Uji Coba Vaksin Corona. Kontan.

Nugroho, A. C. (2020). China Perketat Perbatasan, Cegah 'Imported Case' Covid-19 dari Rusia. Kabar 24.

Perwita, A. A. B., \& Yadi, Y. M. (2006). Pengantar Ilmu Hubungan Internasional. Remaja Rosdakarya.

Pransuamitra, P. A. (2020). Kasus Corona di China Naik Lagi, 
Pasar Bakal Panik? CNBN Indonesia.

RFI. (2020). China Closes Border with Russia As New Cases of Coronavirus Emerge. RFI.

Sagena, U. W. (2013). Memahami Keamanan Tradisional Dan Non-Tradisional di Selat Malaka: Isu-Isu dan Imteraksi Antar Aktor. Jurnal Interdependence, 1(1), 7290. http://e-journals.unmul. ac.id/index.php/JHII/article/ view/1891

Sixth Tone. (2020). Heilongjiang Border Town on Lockdown Over COVID-19 Cases From Russia. Sixth Tone.

Sudiar, S. (2018). Pendekatan Human Security dalam Studi Perbatasan Negara. Jurnal Hubungan Internasional, 7(2). https://doi.org/10.18196/ hi.72139
Teslova, E. (2020). Russia Suspends Visas for Chinese Amid Virus Outbreak. Anadolu Agency.

Wu, H., \& Tian, Y. L. (2020). China Toughens Restrictions on Border With Russia As Imported Coronavirus Cases Hit Record. Reuters.

Yang, G. (2020). China Closes Land Border with Russia to Prevent Imported Covid-19 Cases. CGTN.

Yuliana. (2020). Corona Virus Diseases (Covid-19): Sebuah Tinjauan Literatur. Wellness And Healthy Magazine, 2(1), 187-192. https://doi. org/10.30604/well.95212020

Zhahrina, A. (2020). Kronologi Virus Corona di China, dari Pasar hingga Korea Selatan. Kompas. 